\title{
БИОЛОГИЯ
}

Научная статья. Первая публикация в 1957 г.

УДК $581.9: 598.2(571.54)$

DOI 10.18101/2542-0623-2020-3/4-7-33

\section{ВОДОПЛАВАЮЩИЕ ПТИЦЫ ДЕЛЬТЫ Р. СЕЛЕНГИ (ГУСЕОБРАЗНЫЕ - ANSERIFORMES)}

\section{М. Г. Бакутин}

(C) Бакутин Михаил Григорьевич

кандидат биологических наук, Бурят-Монгольский государственный педагогический институт имени Доржи Банзарова, Россия, 670000, г. Улан-Удэ, ул. Смолина, 6

\section{Для цитирования}

Бакутин М. Г. Водоплавающие птицы дельты р. Селенги (Гусеобразные - Anseriformes) // Природа Внутренней Азии. Nature of Inner Asia. 2020. № 3/4(16). С. 7-33.

DOI: $10.18101 / 2542-0623-2020-3 / 4-7-33$

\section{Из истории орнитологических исследований озера Байкала и бассейна реки Селенги}

Самые ранние сведения о животном мире и, в частности, о птицах оз. Байкал мы встречаем в «Житие» Аввакума, который находился в Сибири в пятидесятых годах XVII в. Описывая природу озера, он указывает и на богатство его животного мира. «Птиц зело много, гусей, лебедей по морю яко снег плавают; рыба в нем осетры и таймени, стерлядь и омули, и сиги и прочих родов много; вода пресная, а нерпы и заиды великия в нем, в океане море большом» [Житие Аввакума, 1904].

Фауна Байкала и прилегающих к нему областей изучалась путешественникаминатуралистами XVIII и XIX вв. - П. С. Палласом, И. Гмелиным, Георги, Г. Радде, Р. Мааком.

Проездом они посещали и дельты р. Селенги. Но в трудах указанных путешественников мы не находим сведений о птицах и, в частности, о водоплавающих интересующего нас района.

Только Р. Маак, проезжавший в дельте 7 апреля 1855 г., в своем описании путешествия на Амур кратко упоминает о встреченных им на пути первых вестниках весны - пролетавших на север небольших стаях сибирских гуменников, отдыхавших на проталинах кряквах и красных турпанах [Маак, 1855]. По этой причине приходится пользоваться материалами по истории орнитологических исследований из других районов оз. Байкала, либо из мест, расположенных на пролетных путях, ведущих в дельту.

О массовом скоплении водоплавающих птиц в бассейне р. Селенги мы находим в описании Гусиного озера декабристом Н. А. Бестужевым, бывшим здесь в 40-х гг. 
прошлого столетия. Вот как он рисует панораму этого озера: «Нигде, кроме острова Осередыша $^{1}$, я не видел такого множества водяных птиц, которые, будучи спугнуты, поднимаются густыми тучами во сей силе слова. Журавли, цапли, гуси, турпаны (красный гусь), утки всех родов, гагарки, пигалицы поднимаются с земли или воды на каждом шагу. Последние надоедают своим писком, кружась над нашей головой из боязни, чтобы вы не разорили их гнезд. Здесь охота за дичью чудесная. Стоит двум охотникам расположиться по обеим сторонам озера, и при выстреле одного вся дичь перелетает к другому, и так по очереди из одного конца в другой.

Но должен также сказать, что надобно сидеть по колено в болоте... По преимуществу водились гуси, которые и дали название озеру Гусиного, и в таком множестве, что еще лет 25 тому назад собирали по берегам около 2 пудов гусиных перьев для письма... Осередыш был главным убежищем этих пернатых, куда обыкновенно собирались промышленники бить палками линных гусей, то есть во время их линяния, когда они не могут летать и держатся охотнее на земле» [Бестужев, 1927].

В. Птицын, посетивший Гусиное озеро в конце XIX в., также отмечает здесь обилие лебедей, гусей и уток [Птицин,1896].

Такое множество водоплавающих птиц водилось тогда и на других водоемах p. Селенги и особенно в ее дельте.

В середине XIX в. на оз. Байкал занимался фаунистическими исследованиями участник Сибирской экспедиции географического общества Г. Радде, который отметил здесь 21 вид водоплавающих птиц. Но эти сведения о птицах имели отрывочный характер. [Радде, 1857].

Глубокое и систематическое изучение фауны птиц началось лишь в 60-х гг. прошлого века неутомимым и энергичным исследователем Байкала Бенедиктом Дыбовским, который вместе со своим спутником В. Годлевским с 1867 и 1869 гг. работал на южном побережье Байкала, в с. Култуке. В течение указанного времени они вели зоологические исследования, особо уделяя внимание орнитофауне. «Самые тщательные и постоянные занятия наши были направлены на орнитологическое исследование фауны Култука», - писали они в своем предварительном отчете о фаунистических исследованиях на Байкале. Менее чем за трехлетнее пребывание в Култуке указанные исследователи собрали богатейший материал по птицам южного побережья Байкала. Ими было констатировано для данного района 260 видов птиц, собраны сведения по биологии, распределению по временам года и стациям отдельных видов птиц. Сделаны были выводы и зоогеографического характера. По этому поводу Дыбовский и Годлевский писали: «Обращаем здесь внимание на тот важный результат, что страна около южной оконечности Байкала лежит на пределе соприкосновения двух различных фаун, именно - одной, характеризующей юго-западную Сибирь, и другой - составляющей особенность юго-востока Сибири» [Дыбовский и Годлевский, 1869].

Все свои коллекции и наблюдения над птицами исследователи отсылали в Варшаву Тачанскому, для издания капитального труда по птицам Восточной Сибири.

В конце прошлого века занимался изучением птиц юго-западного Забайкалья сотрудник Кяхтинского музея В. С. Моллесон. Наблюдения над птицами им производились в окрестностях Кяхты, в районе рек Селенги, Чикоя, Иро и Орхона. Результаты своих орнитологических исследований Моллесон опубликовал в

${ }^{1}$ В то время на Гусином озере был остров, впоследствии исчезнувший. 
протоколе общего собрания Троицкосавско-Кяхтинского отделения Русского географического общества за 1895 г. В 1896 г. Моллесон специально занимался наблюдением весеннего пролета птиц. В своей работе он отмечает особенности весеннего пролета птиц в связи со своеобразными климатическими условиями обследованного района р. Чикой.

Из отряда гусиных для юго-западного Забайкалья указанным натуралистом было отмечено 24 вида, из них 14 в качестве гнездящихся. Из интересных находок, обнаруженных здесь Молессоном, следует указать на факт проникновения в эту часть Забайкалья элемента индо-малазийской фауны - черной кряквы. Следует отметить, что Молессон был первым, признававшим необходимость всестороннего и систематического изучения пролегающего в бассейне р. Селенги пролетного пути гусеобразных.

В 1914-1915 гг. на северо-восточном побережье Байкала работала экспедиция под руководством Г. Г. Доппельмаира. Хотя основная задача указанной экспедиции заключалась в обследовании соболиного промысла, но участники экспедиции попутно занимались и орнитологическими наблюдениями. Для указанного района экспедицией было отмечено 14 видов водоплавающих птиц, в числе которых был найден гнездящимся на гольцовом озере Баргузинского хребта черный турпан [Доппельмаир, 1927].

В 1922 г. в этом же районе занимался изучением птиц С. С. Туров. Из водоплавающих птиц им было отмечено гнездование в районе устья р. Кудалды гоголя.

Результаты своих орнитологических исследований Туров опубликовал в трудах профессоров и преподавателей Иркутского государственного университета [Туров, 1923]. Обширные сведения о птицах юго-западного Забайкалья и прилегающих к нему стран Монголии были собраны Монгольской экспедицией, работающей в 1923-1926 гг. под руководством известного путешественника П. К. Козлова. Орнитологические исследования производились участком экспедиции Е. В. Козловой. Зоологическим отрядом экспедиции был собран огромный материал по птицам - коллекция в количестве 1700 экземпляров к 306 видам и подвидам. Кроме этого, сделано много наблюдений над биологией птиц, их распределением по стадиям, описаны новые формы и границы их распространения. Результаты своих исследований Козлова опубликовала отдельной книгой «Птицы югозападного Забайкалья, Северной Монголии и Центральной Гоби», 1931.

Вторая зоологическая группа Монгольской экспедиции в 1926 г. обследовала район Урги, Хангая, оз. Орок-Нора, Гобийского Алтая. Изучение птиц указанных районов велось А. Я. Тугариновым, отметившим здесь 309 видов и подвидов птиц [Тугаринов, 1929].

В 1932 г. территория Бурят-Монгольской АССР обследовалась комплексной экспедицией, в том числе и в охотничье-промысловом отношении. Участник этой экспедиции Г. А. Новиков занимался изучением промысловой фауны на северо-восточном побережье Байкала. Из водоплавающих птиц для указанного района он отметил 19 видов, в том числе редкий пролетный вид - пискульку.

Наряду с описанием промысловой фауны Новиков останавливается и на вопpocax реконструкции охотничьего хозяйства. В частности, им указывается на необходимость организации в районе среднего течения Верхней Ангары заказника на водоплавающую дичь [Новиков, 1937]. 
В 1933 г. А. В. Третьяков производил орнитологические исследования на острове Ольхон. Из водоплавающих птиц для данного района было отмечено в качестве гнездящихся всего пять видов, что надо объяснить отсутствием здесь подходящих водно-болотных угодий [Третьяков, 1934].

С 1928 по 1938 г. К. К. Вотинцев производил наблюдения над миграцией пластинчатоклювых в районе верхнего течения реки Ангары. В своей интересной работе он дает характеристику пролетным путям отдельных видов водоплавающих птиц, описывает характер весенних и осенних миграций и зависимость их от климатических условий. Для большинства видов указываются сроки прилета и отлета, а также продолжительность пролета. Отмечены особенности осеннего пролета чирка-клоктуна [Вотинцев, 1942].

Интересные сведения о птицах Читинской области мы находим в труде «Птицы и звери Читинской области» заведующего отделом природы Читинского областного музея Е. И. Павлова. Вместе со своими сотрудниками автор названного труда в 1938-1939 гг. исследовал фауну птиц верхнего течения р. Читы, в 1940 г. — юговосточную часть Витимского плоскогорья в районе озер Тасей, Иван и Арахлей.

В своей работе Е. И. Павлов приводит много интересных сведений из жизни птиц и зверей обследованных районов. Для Витимского плоскогорья им описываются 142 вида птиц, в числе которых гусиные представлены 21 формой. К интересной находке следует отнести черную крякву, обнаруженную на гнездовании в районе оз. Тасей [Павлов, 1948].

Автор настоящей работы начал заниматься изучением птиц БМАССР с 1929 г., во время руководства биостанцией Баргузинского района. В весенне-летние месяцы исследование производилось в Чивыркуйском заливе, в районе нижнего течения р. В. Ангары и в долине р. Баргузин.

В 1931 г. наблюдения над птицами производились в долинах рек Аги и Борзи, где на весеннем пролете отмечено большое количество пролетавших на запад малых гуменников.

Летом 1936 г. вместе со студентами-биологами Бурят-Монгольского пединститута я изучал орнитофауну Еравнинских озер.

Здесь отмечено 118 видов птиц, из них гусиных 14 видов.

В названном районе нами впервые наблюдалась в качестве гнездящейся птицы Забайкалья поганка серощекая [Бакутин, 1940].

Особое внимание уделялось дельте р. Селенги как району массового скопления водоплавающей дичи, имеющему важное народнохозяйственное значение.

Данная работа и является результатом наших многолетних исследований гусиных дельты р. Селенги.

Физико-географическая характеристика дельты р. Селенги в связи с основными условиями обитания водоплавающих птиц

Дельта р. Селенги расположена на юго-восточном побережье озера Байкал между селениями Исток, Кабанск, Дубинино. Длина ее по берегу Байкала 40 км,

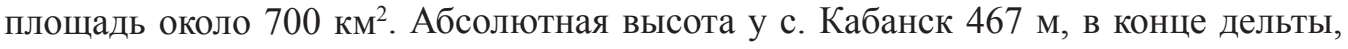
у Харауза - 456 м. При взгляде с самолета вся почти идеальная равнина дельты представляется изрезанной многочисленными веерообразно расходящимися рукавами и протоками, между которыми расположены острова с обширной системой озер и стариц. 
Главными рукавами является Кударинский, отделяющийся вправо от р. Селенги в 10 км ниже с. Кабанск. Против селения Красный Яр от главного рукава Селенги отходит вправо крупный рукав Горбухина, который, в свою очередь, распадается на два потока: Северное устье и Новый Перемой. Еще ниже по течению p. Селенги вправо отделяется рукав Галутай. И, наконец, километрах в 10 от Байкала главное русло р. Селенги распадается на два рукава: левый - Шаманку и правый - Харауз. Последний служит на этом участке для пароходного сообщения. От указанных главных рукавов ответвляется множество мелких протоков, местами переплетающихся между собой и превращающихся в старицы и озера.

Дельта все время растет, вдвигаясь в Байкал, но рост ее неравномерный [Верещагин, 1947]. Лет 60 тому назад рост наблюдался в северных районах, в настоящее время наиболее быстрое нарастание песчаных отложений происходит в южных частях. Росту дельты благоприятствует то обстоятельство, к ней примыкает обширное древнее коренное мелководье, о которое волны Байкала и разбиваются, прежде чем достигнуть слабо закрепленных растительностью молодых илисто-песчаных отложений. Рост дельты происходит довольно интенсивно. За последние 40 лет в районе Харауза дельта увеличилась более чем на 500 метров. Поверхность дельты не остается постоянной, ее различные участки опускаются и затопляются водой. В настоящее время опускание происходит в центральной части. По этой причине в последние годы крупный рыбацкий поселок Харауз был перенесен на новое возвышенное место.

Зарегистрирован случай опускания дельты, имевший характер катастрофы. Зимой 1861 г. вся местность, называвшаяся Цаганской степью, с течение двух дней была залита водой Байкала. На месте бывшей степи в настоящее время образовался залив Провал площадью в 190 км² $^{2}$

Опускание и затопление водой некоторых участков дельты является отрицательным фактором для гнездящихся здесь водоплавающих птиц, которые по этой причине лишаются удобных гнездопригодных угодий. Это заметно в районе протоки Харауза, где за последние годы кряквы почти не гнездятся.

Почвы дельты р. Селенги относятся к болотно-луговому типу [Фетисов и Якубовская, 1947]. Здесь характерно распространение песчаных разностей, развивающихся на аллювиальных отложениях. В некоторых местах имеются слабо оподзоленные суглинистые почвы, местами торфяные. На возвышенных частях дельты встречаются каштановые почвы. Вечная мерзлота, так широко распространенная в Забайкалье, здесь отсутствует, что надо объяснить влиянием Байкала.

Климат дельты континентальный, но несколько мягче, чем в прилегающих к ней соседних районах. Более мягкий климат дельты объясняется умеряющим действием Байкала. Обильны дожди во второй половине лета. В отдельные годы дожди, не прекращаясь, идут неделями. В результате происходят наводнения, при которых затопляется не только низменная часть дельты, но и возвышенная, вместе с пашнями, огородами и селениями.

Кроме крупных наводнений здесь ежегодно в весенне-летнее время происходят обычные паводки, затопляющие пониженные участки дельты. Происходящие ежегодно затопления некоторых районов дельты в значительной мере сокращают гнездопригодные угодья, вынуждая водоплавающих птиц гнездиться среди возвышенных бугров, грив и по берегам проток. Но в то же время затопленные водой 
пониженные места отличаются богатством водно-болотной растительности и служат наилучшими защитными и кормовыми стациями для водоплавающих птиц.

Вследствие небольшого снежного покрова и позднего его образования калтусы и водоемы промерзают на большую глубину, толщина льда доходит до 1,3 м. Сильное промерзание озер и позднее их вскрытие ограничивают распространение уток и нырков в ранневесеннее время. Прилетавшие птицы вынуждены держаться по заберегам и на образовавшихся полыньях. Снежный покров исчезает в начале апреля, за исключением мест, покрытых густыми зарослями тальников, камыша, тростников, где он сохраняется до середины мая. Раннее исчезновение снегового покрова является благоприятным условием для прилетающих гуменников, которые на освободившихся из-под снега хвощевых участках калтуса добывают корм. В июле, с наступлением дождливых дней, уровень воды быстро поднимается, достигая наивысшего предела к концу августа. В таком виде вода и держится до самой зимы. Осенью все заболоченные и пониженные участки дельты бывают сплошь залиты водой. На таких местах, разливах ежегодно отлагается большое количество приносимых водой различных органических и минеральных веществ, являющихся богатым удобрением для развития пышной водно-болотной растительности. В осеннее время места разливов являются характерными станциями отдыха для кормежек различных уток - крякв, шилохвостей, чирков, свиязей и других.

Своеобразие климатического режима и почвенных факторов создают несколько отличные от соседних районов побережья Байкала условия формирования растительных ассоциаций.

Здесь отсутствуют характерные для остального побережья Байкала высокогорные формы растительности, слабо выражены и представители степной флоры. О своеобразии условий развития в дельте растительности Н. А. Коновалов пишет: «Таким образом, влияние р. Селенги как отеплителя, с одной стороны, и отступания вглубь страны горных хребтов, умеряющие влияние оз. Байкал как охладителя, также не дают развиваться степной растительности. Таким образом, исследованный район формирует свои растительные ассоциации под влиянием этих двух факторов, взаимно смягчающих друг друга» [Коновалов, 1930].

Характер растительности, ее распределение на территории дельты зависят также и от возраста речных отложений.

Самая молодая часть дельты, находящаяся в стадии формирования, представляет собой неширокую песчаную полосу, непосредственно примыкающую к Байкалу. На месте молодых песчаных отложений появляется и растительность, которая закрепляет эти наносы. Здесь преобладают осоково-злаковые ассоциации. Характерными растениями - закрепителями песков здесь являются осока дернистая, осока Шмидта, вейник Лангсдорфа. Среди сплошного осокововейникового покрова встречаются куртины тростника, рогоза, манника. Микрорельеф кочковатый. Кочки высотой до $80 \mathrm{~cm}$, образованы самой растительностью - осоками и вейником. Примыкающие к дельте мелководные соры отличаются богатством водной растительности. Плес сплошь местами бывает покрыт ковром нимфейника, кубышки. Почти везде подводные луга рдеста, роголистника, пузырчатки. 
Зимой все прибрежное мелководное пространство промерзает и пересыхает, остаются непромерзшими лишь более глубокие участки соров и подводные борозды рукавов.

В весеннее время, при низком уровне воды, в средней части сора множество песчаных отмелей - лопаток. Большая часть их лишена растительности, только в некоторых местах имеются небольшие куртины камыша, сусака, манника.

Весной эти песчаные отмели служат местом отдыха многочисленных пролетных и гнездящихся стай пернатых. Для пролетающих гуменников лопатки являются излюбленными местами отдыха.

На многих песчаных отмелях встречаются многочисленные гнездовые колонии чаек.

Более глубокие и не промерзающие до дна участки соров по вскрытии их ото льда служат местами массовых скоплений на отдыхе и кормежках многочисленных стай лебедей, шилохвостей, гоголей, чернетей, красноголовых нырков. В осеннее время все песчаные отмели затопляются водой, и в это время на сорах держатся, главным образом, нырковые утки.

Лебеди и гуменники осенью здесь останавливаются сравнительно редко и не в таком большом количестве, как весной. В летнее время прибрежная полоса дельты служит убежищем для молодняка водоплавающих птиц. Среди лабиринта кочек, покрытых густой дерновиной осок, выводки находят хорошую защиту от различных врагов, обильный растительный и животный корм.

Следующая, более старая и возвышенная, часть дельты представлена обширными заболоченными лугами - калтусами со множеством озер и стариц. Из растений для данного района дельты характерны осоково-хвощевые, вейниковые и тростниковые заросли. Берега озер и стариц большей частью низменные и заболоченные, покрыты сплошными зарослями камыша, тростника, рогоза, вейника, манника, осок, вахтой трилистной, хвощем. Возвышенные плотные берега протоков покрыты густыми зарослями ив. Водная поверхность озер и стариц затянута сплошным ковром кубышки малой, кувшинки малой, нифейника. Густые подводные луга рдеста, урути, роголистника, пузырчатки. Весною многие калтусы пересыхают. Места, поросшие хвощом, охотно посещаются гуменниками, которые и питаются этим растением.

Во второй половине лета и осенью все пониженные участки калтусов бывают залиты водой. В это время такие места являются главными стациями отдыха и кормежек тысячных стай различных уток - крякв, шилохвостей, чирков, косаток, свиязей. На крупных озерах в это время обильны гоголи, чернети хохлатые, красноголовые нырки, способные добывать корм на глубине в 4 метра.

Возвышенные места среди калтусов, а также незатопляемые водой берега проток являются характерными гнездовыми стациями различных уток.

Самая возвышенная часть дельты, незатопляемая при обычных паводках водой, занята огородами, пашнями и выгонами.

Для этой части дельты характерна кустарниковая и древесная растительность. Кроме обильно произрастающих ив здесь встречаются таволожник, боярышник, черемуха, рябина, сибирская яблоня. Местами яблони сплошь покрывают острова. Плоды их в осеннее время в большом количестве собираются местными жителями. 
В восточных и юго-западных районах дельты имеются лесные участки, состоящие из сосны, лиственницы, березы, осины. Сплошные лесные насаждения часто чередуются с открытыми осоково-пушициевыми калтусами.

По обилию и массовой концентрации гусеобразные в период с весны до осени являются самым заметным компонентом биоценоза описываемой дельты.

\section{Видовой состав и экология гусиных дельты р. Селенги}

1. Лебедь-кликун Cygnus cygnus (L.)

Бурят-монгольское название - Ехэ хун Сагаан шубуун.

Лебеди-кликуны в большом количестве останавливаются в дельте в пролетное время, особенно весной. Самый ранний прилет кликунов нами наблюдался 11 апреля 1936 г.

Стая в 8 особей появилась около 12 часов дня в районе Байхоровского сора, долго кружилась над льдом и, не найдя подходящего места для отдыха, с криком улетела в юго-западном направлении. Весенний валовой пролет продолжается с 20 апреля по 20 мая. В эти дни стаи кликунов по 20-30 особей беспрерывными вереницами летят в дельту. В ясную погоду перелет не ослабевает и ночью, в это время особенно отчетливо слышны благозвучные трубные звуки пролетающих стай.

Только в густой туман или в сильный ветер со снегопадом перелет приостанавливается, и птицы задерживаются на широких плесах р. Селенги и на озерах. На участке от устья р. Чикой до дельты р. Селенги кликуны летят широким фронтом, придерживаясь северо-западного направления. На указанном пространстве нам не приходилось встречать кликунов отдыхающими на полях или в степи, хотя такие места встречаются здесь повсеместно. На пути в дельту лебеди всегда отдыхают на озерах Гусино-Удинской долины: Гусином, Щучьем, Казенных прудах, Абраменском, Белом и Торминор.

С указанных озер птицы летят в дельту через отроги Хамар-Дабанского хребта, пролетая без отдыха более 100 км.

Любимыми местами отдыха и кормежек для кликунов служат мелководные участки соров, расположенных около устьев протоков Харауз, Голутай, Хирельда, Кольчиха, Колпинная, Среднее устье, Северный Перемой. Эти участки соров раньше вскрываются ото льда, богаче растительными и животными кормами. В первых числах мая здесь лебеди скапливаются тысячами. Днем и ночью они отдыхают и кормятся на одних и тех же местах, совершая перелеты из одного сора в другой перед заходом и восходом солнца. Такие суточные миграции, связанные с отысканием корма, происходят в пределах 6-10 км, при этом лебеди всегда летят одними и теми же путями, вдоль берега Байкала и всегда над льдом или водой.

При опасности они изменяют перелетные пути и летят на большой высоте. Вообще лебеди весьма осторожны. Иногда, сидя в засаде, достаточно бывает чуть пошевелить рукой или ружьем, как летящая стая сворачивает в сторону, а за ней и остальные, хотя они сами не заметили опасности. Будучи ранен, лебедь спасается на открытом сору, на льду, либо затаивается в густой траве или в ледяных торосах. Привязанность супружеских пар друг к другу у кликунов исключительная. Однажды в пролетающей стае была подбита самка, упавшая на открытый сор. На месте падения самки самец безутешно плавал около трех суток и только на третий день перед заходом солнца поднялся в воздух и, сделав над водой несколько кругов, скрылся вдали. 
Основная масса лебедей задерживается в дельте вскрытия льда в этом районе Байкала, что бывает обыкновенно числа 6-9 мая. Как только освободится здесь Байкал, ото льда, лебеди покидают дельту и двумя потоками устремляются к местам гнездования. Часть стай перелетает через озеро в западном направлении и далее по р. Ангаре следует в бассейн р. Енисей. Большая же часть лебедей летит на север вдоль оз. Байкал задерживаясь временно в Чивыркуйском заливе и в районе нижнего течения р. Верхней Ангары, откуда птицы направляются в бассейн р. Лены.

После 10 мая, хотя прилет и не прекращается, больших скоплений кликунов в дельте не наблюдается, так как они задерживаются здесь на короткое время, а нередко без остановки летят через Байкал. Последние прилетающие стаи нам приходилось встречать 23 мая. В настоящее время кликуны гнездятся в дельте единичными парами и спорадически. За время работ только один раз, 2 июля 1934 г., нами наблюдался на Гашейском озере выводок, состоящий из·четырех молодых и двух взрослых птиц. При нашем появлении на озере птицы быстро скрылись в густых зарослях камыша. В зарослях этого растения было обнаружено гнездо кликунов, помещавшееся на заломах камыша, на высоте около полметра от воды. Устроено оно было из старых стеблей камыша за исключением лотка, который был выстлан стеблями осок, вейника и пухом. Прилегающие к камышам заросли осок были сильно измяты, везде следы поедей - общипанные молодые побеги растений. Судя по этому, вегетативные части осок в большом количестве поедались гнездившимися здесь птицами. Кроме дельты р. Селенги на гнездовании кликуны нами наблюдались в Чивыркуйском заливе, на оз. Большой Ранготуй, где 20 июля 1935 г. был найден выводок, состоящий из трех молодых и двух взрослых птиц. Взрослые птицы находились в стадии линьки. У добытого самца маховые и рулевые перья отрасли лишь наполовину. 5 августа первый раз выводок поднялся на крыло и долго перед заходом солнца летал над водой.

На осеннем пролете кликуны не скапливаются в большом количестве в дельте p. Селенги, как и на озерах Гусино-Удинской долины. Первые перелетные стаи появляются в обследованном районе 20 сентября и пролет длится до 23 октября, чередуясь с периодами затишья. Появлению пролетных стай всегда предшествует ненастная погода: северо-западный ветер и снегопад, после чего в течение 2-3 дней происходит интенсивный пролет кликунов. О питании лебедей-кликунов в нашем распоряжении имеется незначительный материал. Всего было просмотрено содержимое 12 желудков у экземпляров, добытых на весеннем пролете, и 1 - на осеннем. Все желудки были заполнены мелким песком с незначительными остатками вегетативных растений, определить которые не представлялось возможным. На местах кормежек кликунов из водных растений характерны рдест пронзеннолистный, роголистник, кубышка малая, нимфейник. У экземпляра, взятого 4 октября на Белом озере, желудок был заполнен илом и озерными бокоплавами. Весили добытые птицы 7,2-10,6 кг.

2. Лебедь малый Cygnus bewicki Yarr.

Бурят-монгольское название - Бага хун Сагаан шубуун.

Лебедь малый в обследованном районе относится к числу пролетных птиц. На весеннем пролете он появляется здесь позже предыдущего вида, обыкновенно в числах 19-21 апреля. Валовой пролет происходит в последних числах апреля и 
продолжается до 15 мая. В эти дни малые лебеди в большом количестве скапливаются в дельте и часто держатся здесь вместе с кликунами. Во время пролета в одной стае иногда летят оба вида, что нетрудно бывает узнать по их различному крику. Голос малого лебедя напоминает громкое «гуканье» и в полевых условиях служит надежным признаком отличия от кликуна.

На осеннем пролете малый лебедь в районе дельты появляется в последних числах сентября, и пролет продолжается до 20 октября.

\section{3. Сухонос Cygnopsis cygnoides (L.)}

Местное название у русских и бурят - Харчун.

В обследованном районе сухонос является обыкновенной гнездящейся птицей, но всюду малочисленен. Прилетают они в дельту чаще всего отдельными парами, реже небольшими стайками, по 6-8 особей, в последних числах марта или в начале апреля. По словам местных охотников, в 1936 г. одиночки-сухоносы появились здесь 21 марта, но вскоре исчезли, так как в это время все водоемы были еще покрыты льдом, а калтусы - снегом. По прилете в дельту птицы держатся на песчаных отмелях и на калтусах, питаясь, главным образом, топяным хвощом. С другими гусями они общаются, но редко. Голос сухоноса — протяжное хриплое гоготание, отчего он и назван местными жителями харчуном.

Через несколько дней после прилета отдельные пары облюбовывают подходящее для устройства гнезда место, поблизости которого потом и обитают. Днем они держатся в стороне от этого места и только с наступлением сумерек прилетают сюда для сооружения гнезда. После того как гусыня начинает кладку яиц, самец держится в стороне, выполняя функции сторожа. При опасности он первый издает предупреждающий голос и начинает летать над подозрительным местом.

Гнездовыми стациями сухоноса служат возвышенные сухие бугры и гривы, покрытые осоковейниковыми зарослями, а также сухие берега проток, поросшие тальниковыми кустами. На гнездование они проникают далеко вверх по горным речкам Абрамихе и Култучной, где и строят гнезда среди густых зарослей вейника. Но выводки в таких местах долго не задерживаются, и родители вскоре уводят своих птенцов на сор. 6 мая 1940 г. недалеко от устья протоки Голутай было найдено гнездо с четырьмя свежими яйцами. Помещалось оно на возвышенном песчаном бугре среди густого осоково-вейникового покрова. Лоток гнезда был тщательно выстлан стеблями осок и пухом. Первый раз гусыня подпустила нас шагов на 10 и только потом, хлопая по траве крыльями и прикидываясь беспомощной, улетела в сторону. Вернулась она спустя минут 20 и не сразу села у гнезда, а сначала долго летала кругом, тщательно высматривая окрестности. Не заметив ничего подозрительного, гусыня села в шагах пятидесяти от гнезда, к которому и пробралась пешком. В следующий раз она была более осторожной и не подпускала нас ближе чем на 50-60 шагов.

9 мая все четыре яйца были взяты из гнезда и 14 мая положены в инкубатор. 11 июня из одного яйца выклюнулся птенец, который и жил в комнате 9 дней. Питался он вареными яйцами, молоком, охотно ловил комнатных мух. К человеку гусенок был весьма привязан и проявлял беспокойство, когда в комнате никого не оставалось, бегал из угла в угол, свистел, прослушивался.

Вообще, молодые сухоносы быстро приручаются, и местные жители всегда их ловят и воспитывают в неволе до глубокой осени. 
В конце июня 1946 г. один путевой обходчик заметил на полотне железной дороги гусыню с пятью пуховиками, пробиравшимися из калтуса в Посольский cop. Трое пойманных гусят через неделю стали совершенно ручными и свободно паслись на улице, поедая молодые побеги пырея, осок и клевера. Они охотно ели печеный хлеб, вареную рыбу, рис, овсянку, просо. В последних числах августа по оперению они не отличались от взрослых, каждый из них весил по 2,5 кг. С этого времени они стали подниматься на крыло и совершать короткие перелеты. С домашними китайскими гусями сухоносы не общались, не спускались и на воду, хотя река и протекала у самого поселка.

В середине сентября сухоносы держатся более открыто небольшими стайками, по 12-14 особей. Последние стаи сухоносов нами наблюдались в дельте 14 октября 1949 г.

В желудке и пищеводе одного экземпляра, добытого в апреле, находились топяной хвощ и осока. Вес его 4,3 кг.

Добываются сухоносы в незначительном количестве.

4. Серый гусь Anser anser (L.)

Бурят-монгольское название - Боро галун.

В настоящее время серые гуси в обследованном районе являются редкими пролетными и гнездящимися птицами. В прошлом веке они были многочисленны в бассейне р. Селенги, о чем можно судить и по описанию Гусиного озера декабристом Бестужевым и по словам старожилов, которые указывали на массовое обитание серых гусей в дельте р. Селенги. Систематический сбор их яиц и добыча линных явились причинами почти полного исчезновения здесь этих птиц. Лет 15 тому назад серые гуси в значительном количестве гнездились в тростниковых зарослях южной части Гусиного озера в районе истока реки Баян-Гол. В данное время они здесь встречаются единичными парами.

На весеннем пролете в дельте стаи серых гусей наблюдались нами 7 апреля 1934 г. По словам местных охотников, они прилетают сюда в конце марта. По прилете птицы держатся на песчаных отмелях в калтусах, особенно в тех местах, где растет хвощ, которым они и питаются.

2 мая 1936 г. недалеко от устья протоки Хирельда было найдено гнездо с двумя свежими яйцами. Помещалось оно среди густой осоки на возвышенном песчаном холме. Недалеко от этого места на тростниковой сплавине было обнаружено второе гнездо с четырьмя яйцами. Из последнего гнезда были взяты 3 яйца, и, несмотря на это, гусыня продолжала кладку.

10 июля на оз. Пневка наблюдался выводок: гусыня с восьмью птенцами. Спасаясь от преследования, один гусенок запутался в сплошном ковре водных растений и был пойман. Вес его был 480 г.

В середине сентября выводки уже поднимаются на крыло и держатся более открыто на песчаных отмелях, калтусах, по старицам. У добытого 17 сентября взрослого экземпляра желудок и пищевод были наполнены метелками манника и хвощом. В окрестностях г. Улан-Удэ последние отлетающие стаи наблюдались 19 октября. Позже этого числа нам не приходилось встречать серых гусей в районе нижнего течения р. Селенги. 
5. Европейский гуменник Anser fabalis fabalis (Lath.)

Бурят-монгольское название - Ехэ галун.

На весеннем пролете эта форма гуменника по количеству особей преобладает над остальными видами гусей, скапливаясь в дельте десятками тысяч. Кроме дельты р. Селенги на территории Бурят-Монгольской АССР, на пролете весной гуменники обильны на северо-восточном побережье Байкала (район нижнего течения р. Верхней Ангары и Чивыркуйский залив), в долинах рек Баргузин, Уда, Тугнуй, Сухара, Хилок, Чикой; на Еравнинских озерах, оз. Гусином, Щучьем, Белом, Кибалино, Боргойской и Тамчинской степях, а также и на пашнях долины р. Селенги.

Первые стаи гуменников прилетают в дельту в начале апреля. 9 апреля 1946 г. мы уже наблюдали сотенные стаи этих птиц кормившимися на хвощевых калтусах в прибрежной полосе дельты между протоками Шаманка и Харауз. Валовой пролет происходит с 16 апреля и до 15 мая. В эти дни гуменники особенно интенсивно летят при северо-западном ветре, при этом движение стай происходит низко над долинами рек и горными хребтами. Если ветер сопровождается сильным снегопадом и горы покрываются сплошной мглой, перелет прекращается и птицы отдыхают на пашнях и степях.

Нам пришлось наблюдать в последних числах апреля 1945 г. обратное движение пролетных стай, когда масса птиц, застигнутая в верховьях рек Убукуна и Оронгоя сильным бураном, в беспорядке возвращалась в районы озер Белое и Кибалино. Но такие случаи редки и происходят лишь в сильное ненастье, когда и на близком расстоянии скрываются земные ориентиры. При перелете через горы, особенно в ненастную погоду, гуменники часто садятся отдыхать и среди горнотаежных калтусов. При перелете с Гусиного озера через Хамар-Дабан птицы часто садятся на обширный калтус, расположенный между реками Абрамиха и Култучная. Вообще гуменники отдыхают в самых разнообразных местах: на пашнях, в степи, на болотах, песчаных отмелях. На воду они садятся сравнительно редко.

По прилету в дельту у гуменников устанавливается определенный суточный режим жизни. Отдыхают они здесь, главным образом, на прилегающих к дельте песчаных отмелях — лопатках и на льду, реже на калтусах. Только в сильный ветер со снегопадом птицы покидают такие места и улетают на калтусы или на пашни как на места, лучше защищенные от ветра. Отдых происходит в дневное время и ночью. Еще до восхода солнца, чуть только на востоке обозначится сероватая полоса, среди отдохнувших стай начинается оживление. Сначала раздается отдельное громкое, отрывистое гоготание гусаков, которым вскоре вторят говорливые голоса пробудившихся остальных птиц. Через несколько минут ночного отдыха беспорядочным строем низко над льдом или калтусом летят кормиться. Перелеты с мест отдыха на кормежку происходит на расстояние 4-6 км. При перелетах на более дальние расстояния стая строится углом или в линию. В дельте гуси кормятся на хвощовых калтусах, в возвышенных районах дельты на пашнях. Последние посещаются в окрестностях селения Дубинина, Красный Яр, Кабанск, Творогово, Исток, Посольск. В первой половине мая они пасутся на зеленых всходах хлебов, сильно вытаптывая и объедая посевы. Кормятся гуси часов до 10-11 утра, после летят на старые места отдыха, где и находятся до 4-5 часов дня. В пятом часу 
они снова летят кормиться, возвращаясь на ночлег с наступлением темноты, часов в 9-10 вечера. Такого суточного режима гуменники строго придерживаются в течение всего времени пребывания в дельте.

Некоторые натуралисты отмечают, что перед отлетом стай на кормежку предварительно летят на разведку местности отдельные старые гусаки, которые возвращаются обратно и извещают остальных о безопасности полета, или наоборот.

Такого факта нам не приходилось наблюдать. В период охотничьего сезона одиночные гуси, с беспокойством летавшие над окрестностям с целью отыскания потерянного самца или самки, не раз нами наблюдались. В подтверждение сказанного приведем такой случай. 12 апреля 1946 г. около устья протоки Шаманка удачным выстрелом из пролетавшей стаи была взята гусыня. Сразу же вслед за падающей самкой из стаи вылетел гусак и с криком стал кружится над упавшей гусыней. Долго он здесь летал, садился около убитой и снова кружился в воздухе. Только после выстрела, правда, неудачного, он улетел в сторону. К вечеру гусак снова вернулся на это место. На завтра утром он опять показался здесь и с тревожным криком рассматривал потерянную гусыню. Что это был тот самый гусь, в этом не было сомнений, так как от первого неудачного выстрела у него не стало махового пера и с таким ущербленным крылом он был хорошо заметен.

Большинство гуменников покидают дельту после вскрытия в этом районе Байкала от льда.

После 10 мая, хотя и продолжается пролет гуменников, но не так напряженно, и птицы задерживаются в дельте на короткое время, а нередко без остановки летят через Байкал в западном, северо-западном и северном направлениях.

На осеннем пролете гуменники в дельте Селенги чаще появляются с 16 сентября. Пролет происходит отдельными волнами и длится до 23 октября. 3a 2-3 дня до появления стай дует северо-западный ветер со снегопадом. В нижнем районе дельты на осеннем пролете гуменники задерживаются редко и в небольшом количестве. Осенью эта часть дельты бывает затоплена водой и птицы лишаются мест отдыха и кормежек. В этот сезон гуменники держатся, главным образом, на пашнях, питаясь здесь хлебными зернами, особенно охотно они посещают пшеничные поля. Следовательно, если весной в дельте Селенги происходит концентрация огромных стай гуменников, то осенью мы почти их здесь не имеем. Гуменники летят на зимовку, не останавливаясь в дельте совершенно или задерживаясь здесь лишь отдельными стайками; или, минуя дельту, летят на восток вдоль Байкала или же через Хамар-Дабан по долине Снежной в бассейны Хилка и Чикоя. В этом мы отмечаем существенное отличие весеннего и осеннего пролетов в дельте Селенги гуменников и других видов гусей.

6. Лесной гуменник Anser fabalis sibiricus (Alph.)

Бурят-монгольское название то же, что и предыдущего вида.

Самый крупный из всех гуменников. Прилетает в дельту несколько раньше европейского гуменника и небольшими стаями. В окрестностях r. Улан-Удэ на весеннем пролете наблюдался 30 марта. На отдыхе и кормежках лесной гуменник часто держится вместе с предыдущей расой. О гнездовании лесного гуменника в обследованном районе у нас нет наблюдений. 
Дыбовский и Годлевский относят его к числу гнездящихся птиц на Байкале. По сообщению Э. Э. Пильмана, в летние месяцы 1949 г. стайки лесных гуменников встречались в верховьях р. Турки.

В полевых условиях обе расы этих гуменников почти не различимы, хотя лесной заметно крупнее европейского.

Наиболее устойчивым признаком отличия служат формы и размеры клюва. У европейской расы в среднем длина его от оперения до лба 5,8 см. Лесной гуменник обладает более массивным клювом с длиной его в среднем 7,5 см.

На протяжении нескольких лет были измерены 172 клюва у особей, добытых на весеннем пролете в различные годы.

Только у 50 особей длина клюва в среднем была 7,5 см, у остальных $122-$ 5,8 см. Из этого следует, что в районе дельты р. Селенги на весеннем пролете европейский гуменник количественно преобладает над лесным. Наши выводы о количественном соотношении этих форм гуменником согласуются с наблюдениями Е. В. Козловой над весенним пролетом этих птиц- в Северной Монголии, которая также отмечает преобладание европейского гуменника над лесным.

Отдельные экземпляры весили 5,2 кг.

7. Малый гуменник Anser serrirostris rossicus But.

Малый гуменник в большом количестве встречается на весеннем пролете в дельте р. Селенги и в других районах Бурят-Монгольской АССР. На весеннем пролете он появляется здесь числах в 20-25 апреля, и пролет продолжается до конца мая. Валовой пролет происходит в первой половине мая. В этот период гуменники в большом количестве останавливаются на отдыхе и кормежках на полях Гусино-Удинской долины и на озерах Еравнинских, Гусином, Камышевом, Щучьем, Белом, держится большей частью отдельно от остальных гуменников.

Отдельные стайки гуменников остаются на лето в обследованном районе и ведут бродячий образ жизни. На песчаном берегу р. Селенги, недалеко от Ганзурино, в конце июня нами наблюдалась стая в 22 особи. После выстрелов птицы быстро снялись с отмели и, пролетев метров 200, снова опустились на песок. Добытые две гусыни были сильно истощенными и с недоразвитыми яичниками. Зобы их были до отказа наполнены стеблями осок. Одна из них весила 1,6 кг, другая $-1,8$ кг. На осеннем пролете малые гуменники появляются 19-21 сентября, и пролет длится до 20 сентября.

Среди наших орнитологов нет единого мнения о видовой самостоятельности малого гуменника. А. Я. Тугаринов в своей капитальной работе по пластинчатоклювым рассматривает малого гуменника как тип личной изменчивости европейского гуменника. В результате многолетних наблюдений над малым гуменником в полевой обстановке и сравнений многих добытых экземпляров с другими встречающимися в дельте расами мы склонны считать его самостоятельным видом.

Малый гуменник, как это совершенно правильно указывает Бутурлин, отличается от европейского формой и размерами клюва [Бутурлин, 1935]. Своей меньшей величиной он даже в полевой обстановке легко отличается от других гуменников, с которыми к тому же редко и смешивается. На весеннем пролете он появляется позже остальных. Полет и голос у него как-то торопливее и «говорливее». Местные охотники малого гуменника хорошо отличают в природе как «малого гуся», прилетающего позже остальных. Указанные признаки нельзя не считать видовыми. 
О питании останавливающихся в дельте р. Селенги на весеннем пролете всех видов гуменников можно сказать следующее. Нами были вскрыты и просмотрены 266 зобов и желудков. Более половины из них (197) оказались заполненными топяным хвощом. В меньшем количестве мы встречали молодые побеги осок, зерна пшеницы, горох, метелки манника и в одном случае - ягоды клюквы.

В районе дельты р. Селенги хвощовые болота служат основным местом кормежки гусей.

Домашние животные, в частности лошади и коровы, не едят топяной хвощ, вероятно, по причине содержащегося в нем ядовитого вещества — алкалоида эквизетина, который проявляет свое ядовитое действие в организме этих животных.

Гуси без вреда для себя поедают это растение.

\section{8. Белолобая казарка Anser albifrons albifrons (Scop.)}

Белолобая казарка - обитательница арктической тундры. В описываемом районе она относится к числу редких пролетных птиц. 8 мая 1934 г. из стаи в 13 особей были добыты две птицы. Желудки их оказались заполненными зернами пшеницы. Каждая из птиц весила 2,4 кг. На другой день стая этих птиц отдыхала на песчаной отмели в устье протоки Голутай. На осеннем пролете стая казарок около 40 штук была замечена 13 октября в окрестностях г. Улан-Удэ.

Ближайшим местом, где белолобые казарки обильны на пролете, является бассейн р. Лены в районе г. Якутска [Иванов, 1929].

9. Малая белолобая казарка Anser erythropus (L.)

Редкий пролетный вид. Только один раз, 8 мая 1934 г., мы слышали характерный пискливый голос этой птицы, летевшей вместе с белолобыми казарками. По сообщению Э. Э. Пильмана, на весеннем пролете пискулька им была отмечена в долине р. Хилок. Новиков наблюдал эту казарку на пролете в районе нижнего течения р. Верхней Ангары. Других наблюдений и сведений о малой белолобой казарке у нас не имеется.

10. Индийский гусь Eulabeia indica (Lath.)

Индийский гусь является обитателем высокогорной Центральной Азии. В районе дельты р. Селенги редко появляется в качестве залетной птицы. Единственный раз, 29 июля 1947 г., мы встретили пару этих птиц отдыхающими на песчаном берегу Посольского озера, около устья р. Толбозихи. Не исключена возможность гнездования его на озерах Хамар-Дабанского хребта.

\section{1. Пеганка Tadorna tadorna (L.)}

Редкий залетный вид. В дельте р. Селенги только один раз, 9 мая 1946 г., мы встретили на сору пару пеганок. Второй раз шесть этих птиц мы встретили 7 сентября на Белом озере.

\section{2. Красный турпан Casarca ferruginea (Pall.)}

Бурят-монгольское название - Шара ангир.

Обыкновенная гнездящаяся птица долины р. Селенги и ее притоков. Прилетает турпан отдельными парами в числах 19-22 марта. Пока еще водоемы покрыты льдом, птицы чаще всего держатся на пашнях, питаясь прошлогодними хлебными зернами. Нередко они отдыхают на льду, или снегу. Характерными гнездовыми стациями красных турпанов являются малодоступные утесистые скалы по 
берегам рек. В расщелинах таких скал и устраиваются гнезда. Часто они гнездятся среди скал в тайге на значительном расстоянии от воды, километрах в 6-7. 29 мая мы нашли 8 яиц с почти оформившимися зародышами в старом гнезде черной вороны на развесистом ильме, росшем на отвесном скалистом берегу р. Селенги. К гнездованию турпаны приступают в последних числах апреля. Во время высиживания самец всегда находится поблизости гнезда, устроившись где-либо на скале или дереве. При опасности он первый взлетает и с криком кружится над окрестными местами. Самые ранние кладки яиц нами наблюдались 27 апреля, но иногда и в первых числах июня приходилось встречать гнезда с 4-5 яйцами. Как только появятся птенцы, родители их сразу уводят к ближайшему водоему. 3 июля 1935 г. в окрестностях г. Улан-Удэ нами наблюдался выводок, спускавшийся с горы на р. Селенгу. Самка вместе с пуховиками быстро передвигалась по траве, изредка покрикивая, самец в это время сидел на ближайшей скале и, заметив нас, быстро взлетел и с криком стал кружиться над выводком. Вслед за ним и самка поднялась в воздух, и обе птицы тревожно летали над затаившимися в траве своими птенцами. На легкое прикосновение руки птенцы не реагировали и продолжали лежать, плотно прижавшись к земле.

Застигнутые врасплох на воде, птенцы быстро ныряют и прячутся в прибрежной траве. На небольшом озере среди Мухинских болот 14 июля мы встретили 7 молодых турпанят, величиной с чирка. Поймать их на озере, хотя оно и было небольшим, не было никакой возможности. Пришлось раздеться и, погрузившись в воду до подбородка, ждать пока они выплывут на середину озера. Вскоре турпанята стали спокойно плавать у самого носа и ушей, и их легко можно было брать снизу рукой и выносить на берег. После нескольких таких приемов вскоре все птицы были переловлены и окольцованы.

Выводки разных возрастов собираются в стаи с конца июля. В начале августа нам приходилось встречать на Посольском сору стаи по 30-40 особей, среди которых находились молодые с едва пробивавшимися контурными перьями.

Отлет красных турпанов начинается с середины сентября и продолжается до 10 октября. На осеннем пролете стаи турпанов держатся большей частью на открытых степных озерах, а также и на плесах р. Селенги.

Пища турпанов разнообразная. В их желудках мы находили зерна пшеницы, плоды осок, моллюсков, бокоплавов, озерных гольянов и мелких хариусов. 28 апреля на пашне около Белого озера мы встретили пару этих птиц вместе с черными воронами, поедавшими остатки погибшей овцы.

Как птицы весьма осторожные и не обладающие к тому же вкусным мясом, турпаны не имеют промыслового значения и добываются здесь единицами.

13. Кряква Anas platyrhyncha platyrhyncha (L.)

Бурят-монгольское название - hоно ногоһон.

Из всех уток кряква самая обыкновенная и широко распространенная на гнездовании в дельте р. Селенги и в других районах Бурят-Монголии. Прилетает она в дельту в конце марта или в начале апреля, когда еще водоемы покрыты льдом. Первые дни по прилете птицы ютятся по заберегам, на калтусах, песчаных отмелях, нередко их можно встретить отдыхающими на льду. 
В течение первой половины апреля прилет выражен слабо и утки летят парами или небольшими стайками, по 4-6 особей. Валовой пролет начинается с 15 апреля и длится до первых чисел мая. В этот период кряквы беспрерывно летят над долинами рек стайками по 20-30 особей.

В зависимости от хода весны пролет бывает различным. Когда весна ранняя и стоят теплые дни, утки летят постепенно, не скапливаясь в больших количествах на пути в дельту.

При поздней и холодной весне пролет отличается кратковременностью и массовым появлением крякв на местах временного отдыха.

Лет происходит при самых различных метеорологических условиях: при северозападном ветре, снегопаде и дожде. Только при сильном и холодном юго-восточном ветре пролет ослабевает, а иногда и совсем приостанавливается.

Днем кряквы чаще всего отдыхают и кормятся на озерах и тихих заводях долины р. Селенги. С наступлением вечерней зари начинается движение стай и лет продолжается до самого утра.

По вскрытии р. Селенги ото льда часто по несколько часов подряд они пассивно плывут вместе с шугой вниз по течению. Этим способом передвижения, не требующим затраты мышечной энергии, пользуются и другие утки, если только течение реки совпадает с направлением пролетных путей.

В отличие от лебедей и гуменников, утки в районе нижнего течения p. Селенги избегают перелетов через горные хребты и следуют всегда над долинами рек, где они могут почти в любом месте остановиться на отдых и кормежку.

Конец апреля и первая декада мая характеризуются массовым скоплением крякв в дельте р. Селенги. В это время утки здесь повсеместно обитают в прибрежной мелководной части, на мелких озерах и старицах, на калтусах и песчаных отмелях. В меньшем количестве они держатся на открытых озерах и сорах.

В конце апреля, а иногда и раньше кряквы приступают к гнездованию. 21 апреля нам приходилось находить гнезда с 2-3 свежими яйцами. До 15 мая большая часть их заканчивает кладку яиц, и с этого времени оставшиеся в одиночестве селезни ведут кочевой образ жизни.

Гнезда устраиваются в различных местах, но чаще на возвышенных, не затопляемых водой. По причине частых наводнений в нижней части дельты кряквы, как и остальные утки, гнездятся в малом количестве, хотя здесь защитные и кормовые угодья богаче, чем в остальных районах. В низовьях дельты гнезда строятся на высоких кочках, буграх и гривах под защитой густой дернины, осок и вейников. Нам приходилось находить в этой части дельты гнездящихся крякв в старых заброшенных гнездах серых цапель среди густых тростниковых зарослей (остров Часовенский), на тальниковых кустах в старых гнездах черных ворон или на полуразвалившихся ондатровых хатках (остров Харауз).

Большая часть крякв гнездится на возвышенных плотных берегах проток среди и ивовых зарослей, осок и вейников. Особенно много гнезд там, где берега изрезаны мелкими заливами с обильной растительностью: тростником, камышом, рогозом, осоками, вейником, нимфейником, кубышкой малой и кувшинкой малой. Среди этих мест выводки находят хорошую защиту и обильный корм. На гнездование кряквы проникают далеко вверх по горным речкам Толбозихе, Абрамихе, 
Культучной. Так же как и в пище, в выборе гнездовых стаций кряква неприхотлива и способна селиться в самых различных местах, часто в необычных для утиного рода, в горно-таежных районах, где нет ни озер, ни болот, и птицы довольствуются небольшими плесами горных речек.

По нашим наблюдениям, кряква может производить вторую кладку яиц. 9 мая 1948 г. на берегу протоки Голутай было обнаружено гнездо с десятью слабо насиженными яйцами, из которых 8 поступили в коллекцию. Вторичная кладка началась на третий день и потом ежедневно в гнезде появлялось лишнее яйцо. Последнее по счету шестое новое яйцо было отложено через день после пятого.

Выводки в возрасте не более недели нами наблюдались 8 июня. Первое время молодняк вместе с маткой держится скрытно на глухих озерах, старицах и протоках, среди густой прибрежной растительности.

В начале августа молодняк способен подниматься на крыло и с этого времени выводки объединяются в стаи, совершая перелеты с мест отдыха на кормежку. В августе и в первой половине сентября перелеты на кормежку происходят до захода солнца. Позже этого времени и до момента отлета утки летают на ночную жировку с наступлением темноты. Возвращение на дневной отдых происходит рано утром. В районе дельты такие перелеты совершаются в пределах 6-10 км. Не везде утки по вечерам и утрам летят на новые места. На разливах, где среди густой разнообразной растительности много корма и надежная защита, они обитают круглые сутки, лишь только вечерами и утрами летают над окрестными местами.

Осенью разливы (пониженные участки калтусов) являются местами массовых скоплений различных видов уток.

В районе селений Дубинина, Красный Яр, Творогово, Шигаево, Исток, Посольск кряквы в большом количестве кормятся на пшеничных и овсяных полях.

Отлет на места зимовок начинается обычно 25 сентября и продолжается до 20 октября. В последних числах октября все утки покидают дельту, кроме нырков и крохалей, которые здесь задерживаются до конца ноября. Среди горных речек нам приходилось встречать стаи крякв вместе с чирками-свистунками 6 ноября.

Питается кряква разнообразной пищей. Нами было просмотрено содержание 213 зобов и желудков у экземпляров, добытых в разные сезоны года. В питании кряквы преобладают семена осок, водяной гречихи, кувшинки, вахты трилистной и др. Из животных кормов поедаются моллюски и гаммариды.

Осенью в дельте р. Селенги кряквы являются главными объектами промысловой охоты и по количеству добываемых особей занимают первое место среди остальных видов уток.

14. Черная кряква Anas poecilorhyncha zonorhyncha $\mathrm{Sw}$.

Черная кряква обитает в юго-западном Забайкалье в качестве редкой гнездящейся птицы. В дельту она прилетает парами в середине мая и встречается чаще всего на протоках, по старицам и на сорах в прибрежной полосе дельты. Держится она отдельно от других уток, но иногда кормится вместе с кряквами. Выводок, 8 птенцов и 2 взрослых утки, мы нашли 20 июля 1935 г. на южном берегу Гусиного озера среди тростниковых зарослей (исток р. Баян-Гол). Добытая взрослая птица оказалась самцом. В его желудке, а также в желудке пухового птенца находились мелкие саранчовые. 
Интересна биологическая особенность черной кряквы: самец не только находился около выводка, но, так же как и самка, при виде нас стал беспомощно хлопать по воде крыльями, хотя он и был в полном пере, за исключением начавшейся линьки мелкого пера на груди.

По словам натуралиста Э. Э. Пильмана, черная кряква гнездится на горном озере Таглей (верховье р. Темника).

В юго-восточной части Витимского плоскогорья в районе оз. Тасей Е. И. Павлов добыл самку, в яйцеводе которой было вполне сформировавшееся яйцо [Павлов, 1948].

Таким образом, вопреки мнению Е. В. Козловой и Б. К. Штегмана, факт гнездования этого интересного представителя Индо-Малайской фауны в юго-западном Забайкалье является установленным.

15. Серая утка Anas strepera (L.)

Бурят-монгольское название - Боро ногоһон.

В небольшом количестве встречается на пролете и в гнездовое время. Пролет отдельных пар и небольших стай в районе дельты отмечен 14 апреля. Отдыхают и кормятся серухи на мелководных местах прибрежной полосы дельты, по старицам и мелким озерам. К гнездованию приступают в первых числах июня. На острове Харауз 5 июня мы нашли гнездо с четырьмя свежими яйцами. Устроено оно было на небольшом бугре среди густой дернины осок. Поблизости гнезда на небольшой лужайке находился селезень, который и был добыт. Желудок его был заполнен мелкими камешками, зелеными стеблями осок и измельченными раковинами моллюсков.

6 августа на оз. Пневка мы нашли выводок серухи - матку с семью полувзрослыми птенцами. Добытый молодой экземпляр весил 280 гр. В желудке его находились раковины моллюсков.

Кроме дельты р. Селенги выводки серух нам приходилось встречать в Чивыркуйском заливе и на Камышовом озере Гусино-Удинской долины. Всюду она малочисленна.

На осеннем пролете стайки серых уток мы наблюдал 12 октября на озерах Белом и Торминор.

16. Косатка Anas falcata Georg.

Косатка широко распространена на гнездовании в юго-западном Забайкалье и обыкновенна в районе дельты р. Селенги.

На весеннем пролете она появляется стайками по 12-20 особей в середине апреля. 14 апреля 1946 г. нам приходилось в прибрежной полосе дельты между протоками Шаманка и Харауз встречать их вместе с кряквами на образовавшихся проталинах.

Валовой пролет начинается с 25 апреля и длится до 20 мая. В этот период времени косатки многочисленны на всех озерах Гусино-Удинской долины.

На пролете, а также и на отдыхе косатки нередко держатся вместе со свиязями и чирками-клоктунами.

К гнездованию эта утка приступает поздно, в середине июня. 19 июня на берегу протоки Мотоихи под густым кустом ивы мы нашли гнездо с пятью яйцами, 
помещалось оно на земле в небольшом углублении, тщательно было замаскировано стеблями осок и устлано ими с примесью сухих листьев ив и пуха.

Гнездятся косатки и по горным речкам Толбозихе и Абрамихе, где нам приходилось встречать их выводки 17 и 25 июля.

В числах 12-14 сентября замечается отлет косаток. Во второй половине сентября и до 15 октября они в большом количестве задерживаются на озерах долины р. Селенги.

Кроме дельты р. Селенги выводки этих уток мы встречали в Чивыркуйском заливе, на Еравнинских озерах, в долинах рек Хилок и Темник. Гнездится она и в окрестностях г. Улан-Удэ среди Мухинских болот.

Вес некоторых птиц был 720 грамм.

Пищей косатки служат стебли топяного хвоща, семена камыша, рдеста, моллюски. В желудках этих уток мы чаще всего находили семена камыша и моллюсков.

17. Шилохвость Anas acuta (L.)

Бурят-монгольское название - Шубэгэ һуултэ. Среди всех уток шилохвость самая многочисленная и на весеннем пролете в дельте р. Селенги, скапливается тысячными стаями. Прилет их в дельту отмечен 13 апреля.

Валовой пролет начинается с 20 апреля и продолжается до 15 мая. В течение этого времени сотенные стаи шилохвостей беспрерывно тянут над долинами рек. На пути в дельту они обильны на отдыхе среди озер Гусино-Удинской долины: Гусином, Щучьем, Камышовом, Казенных прудах, Абраминском, Кибалино, Белом и Торминор.

В районе дельты основная масса этих уток отдыхает и кормится в прибрежной полосе соров. Часто они располагаются вокруг отдыхающих здесь стай лебедей и в таком множестве, что последние кажутся ледяными островками, особенно выделяющимися среди окружающей сплошной темной массы шилохвостей. Большое оживление они вносят в весенний ландшафт дельты. Ежедневно по утрам и вечерам сотенные стан этих уток с шумом и свистом крыльев стремительно рассекают воздух и носятся во всех направлениях. Своей массовостью и стремительными полетами они увлекают и других уток, которые срываются и носятся в беспорядке над озерами и калтусами. Такие воздушные «игры» происходят отдельными волнами, чередующимися с периодами покоя.

В середине мая количество шилохвостей заметно уменьшается, большая часть их покидает дельту и летит через Байкал. Оставшиеся разбиваются на пары и уединяются на гнездование. В дельте шилохвости гнездятся в небольшом количестве. Кладки по 4-6 яиц нам приходилось встречать 30 мая и 5 июня.

Гнезда устраиваются на возвышенных местах калтусов среди густого осоковейникового покрова, по берегам протоков в тальниковых кустах и на камышовых сплавинах.

Пуховых птенцов мы встречали на небольших озерах и старицах 30 мая и в первых числах июля. Молодые поднимаются на крыло в конце августа, и с этого момента выводки объединяются в стаи. В первых числах сентября скопление шилохвостей бывает на разливах и в прибрежной полосе дельты.

Отлет на юг начинается 10 сентября и длится до середины октября. 14-15 октября нам приходилось встречать большие стаи шилохвостей на озерах долины р. Селенги. 
Основным кормом шилохвости весной служат семена вахты трилистной, осок, камыша и моллюска. Осенью к этому добавляются семена рдеста и водяной гречихи.

18. Свиязь Anas penelope (L.)

Будучи многочисленными на весеннем и осеннем пролетах, на гнездовании в дельте р. Селенги свиязи остаются в небольшом количестве. Прилет первых стай нами наблюдался 17 апреля. Валовой пролет начинается обычно с 20 апреля и длится до 15 мая. В течение этого времени свиязи многочисленны на озерах Гусино-Удинской долины.

Летят свиязи чаще всего в ночное время и на утренней заре, днем они кормятся на мелких озерах и протоках.

Во второй половине мая большая часть свиязей покидает дельту и улетает гнездиться в северные районы; оставшиеся пары удаляются на гнездование. Гнездование стации свиязей те же, что и у кряквы, и нам приходилось встречать гнезда этих уток поблизости одно от другого. Так, 2 июня на сухом берегу протоки Першинской было найдено гнездо с 4 яйцами, шагах в 10-12 от него находилось гнездо кряквы с 11 яйцами. первые выводки в возрасте не более недели мы встречали на Гашейском озере 18 июля.

На осеннем пролете стаи свиязей отмечены 17 сентября. Отлет продолжается до 20 сентября.

О питании свиязей в нашем распоряжении имеется следующий материал: у 19 особей, добытых весной, в 4 желудках были стебли топяного хвоща, в 7 - зеленые стебли осок и их плоды, в 9 - семена камыша и в 3 - моллюски. У особей (12 штук), взятых осенью в желудках, обнаружены: в 5 - семена камыша, в 9 семена осок, в 3 - вахты трилистной.

19. Широконоска Anas clypeata (L.)

Бурят-монгольское название - Шарха хоншоор.

Немногочисленна на пролете и гнездовании в дельте р. Селенги и в других районах Бурят-Монголии. Весною широконоски пролетают стайками по 4-6 особей. Прилет первых птиц был замечен 3 мая. В дельте широконоски чаще всего встречаются в прибрежной полосе и на старицах, иногда они отдыхают и на калтусах.

Гнездо с девятью свежими яйцами найдено было 8 июня на сухом берегу небольшого озера (остров Харауз). Помещалось оно на кочке среди густой дернины осоки. На этом же озере 13 июля был замечен выводок: матка и 8 пуховых птенцов.

Кроме дельты выводки широконоски мы наблюдали в Чивыркуйском заливе, на Еравнинских озерах, Камышевом озере и на Мухинских болотах. Везде она малочисленна.

На осеннем пролете стайки широконосок замечены 7 сентября. Последний раз мы наблюдали 9 птиц на оз. Белом 2 октября. У самца, добытого 3 мая, в желудке оказались мелкие стебли осок и моллюски. Вес его - 600 граммов.

20. Чирок-трескунок Querduedula querduedula (L.)

Бурят-монгольское название - Шурхы.

Чирок-трескунок в описываемом районе гнездится в небольшом количестве. Первые парочки трескунов наблюдались в дельте 29 апреля. Пролет длится до 
последних чисел мая. По прилете эти чирки держатся по старицам и глухим протокам. Встречаются они также и по горным речкам, где и гнездятся. Вообще чирок-трескунок избегает открытых соров и озер, а если и держится здесь, то у самых берегов среди густой растительности. Гнездовыми стациями являются возвышенные берега стариц и речек с густой растительностью. 26 июня на берегу горной речки Толбозихи мы нашли гнездо с девятью сильно насиженными яйцами. Пуховиков нам приходилось встречать 19 июля (р. Абрамиха).

Отлет на зимовку начинается 8 сентября и длится до 10 октября. В отдельные годы небольшие стайки трескунов задерживают на озерах долины р. Селенги до 16 октября.

У 9 особей, добытых в мае, в желудках обнаружены семена осок, камыша и моллюски.

\section{1. Чирок-свистунок Querduedula crecca (L.)}

Бурят-монгольское название - hоно.

В большом количестве встречается на пролетах и гнездовании в дельте p. Селенги. На весеннем пролете первые стайки появляются 16 апреля. По мере освобождения водоемов от льда количество чирков увеличивается, и в первой половине мая они встречаются в большом количестве в прибрежной мелководной полосе соров, на старицах и протоках. Обыкновенен он также и по горным речкам. Там, где берега водоемов затоплены водой и покрыты густой растительностью, свистунки держатся особенно охотно, скапливаясь сотнями.

К гнездованию они приступают в последних числах мая. Гнезда помещаются на возвышенных местах калтусов среди густой осоки, по берегам протоков, поросших тальниковыми кустами. Кладки в 3-4 яйца нам приходилось встречать 4 июня. Пуховые птенцы наблюдались 24 июня и 5 июля.

В последних числах августа большая часть молодняка способна летать и с этого времени объединяется в стаи. В сентябре и в первой половине октября чиркисвистунки в большом количестве скапливаются на разливах.

Осенний отлет начинается с 6 сентября и заканчивается 13 октября. Весь этот период чирки обильны на всех озерах Гусино-Удинской долины. По горным речкам (Гильберя и Оронгой) мы встречали чирков-свистунков вместе с кряквами 6 ноября.

Весною этот вид чирка питается, главным образом, плодами осок, камыша и водяной гречихи, осенью такой же пищей, но часто встречались плоды вахты трилистной.

\section{2. Чирок-клоктун Querquedula formosa (Qeorgi)}

Бурят-монгольское название - Эреэн толгойто һоно.

Клоктун в районе дельты р. Селенги является пролетной птицей и встречается в небольшом количестве. Весной первые стайки клоктунов прилетают в дельту 20 апреля и держатся здесь до середины мая. Места отдыха и кормежек их те же, что и у свиязей и косаток, с которыми клоктун часто и летит. В летние месяцы нам приходилось встречать одиночных птиц, но они, надо полагать, являются случайно отставшими подранками.

На осеннем пролете здесь клоктуны появляются 7 сентября и держатся до середины сентября. В окрестностях г. Улан-Удэ отлет клоктунов наблюдается 18 сентября. 
Некоторые наши орнитологи считают, что клоктун в осеннее время на места зимовок летит другими путями. Так, по мнению А. Я. Тугаринова, осенью клоктуны летят «восточнее, вдоль Охотского побережья». Основанием для такого вывода служит якобы полное отсутствие клоктуна в осеннее время на путях весеннего пролета. Если клоктун на осеннем пролете мало заметен, то это объясняется, как правильно замечает К. К. Вотинцев, его относительно небольшим количеством, коротким пролетным сроком и мало заметными отличиями в осеннем наряде от других видов уток. Из местных охотников мало кто знает этого чирка.

При осмотре желудков у 8 птиц, добытых весной, были обнаружены плоды осок, кувшинки малой и моллюски.

\section{3. Красноголовый нырок Nyroca ferina (L.)}

B большом количестве появляется в дельте на весеннем и осеннем пролетах. На гнездовании он здесь также обыкновенен. Прилет в дельту отдельных стай отмечен 23 апреля. Валовой пролет начинается с начала мая и длится до конца этого месяца. Весь этот период красноголовые нырки обильны на всех озерах ГусиноУдинской долины.

Стациями отдыха и кормежек служат прибрежная полоса соров, старицы и мелкие озера. Кормится он часто вместе с кряквами, шилохвостями.

Гнездится по глухим протокам и озеркам, где берега покрыты густой растительностью, камышом, тростником, рогозом, осоками.

21 июня мы нашли на камышовой сплавине оз. Копанец гнездо с сильно насиженными яйцами. Построено оно было из стеблей камыша, лоток устлан осокой. Птенцов в возрасте 3 дней нам приходилось видеть по старицам 19 и 26 июля. В середине августа молодняк способен подниматься на крыло, и с этого времени он держится стаями на открытых плесах озер.

На осеннем отлете красноголовые нырки собираются большими стаями и держатся на сорах и тихих протоках.

С середины сентября наблюдается отлет на зимовку. Последние стаи задерживаются на озерах Гусино-Удинской долины до 20 октября. Пищей для этого нырка служат зеленые стебли и плоды осок, семена камыша, гаммариды.

24. Чернеть хохлатая Nyroca fuligula (L.)

Бурят-монгольское название - Шунгадаг.

В большом количестве гнездится в дельте р. Селенги и по всем озерам Забайкалья.

Появление первых стай отмечено 25 апреля. Валовой пролет длится весь май. На отдыхе и кормежке хохлатые чернети держатся на сорах и крупных озерах. В период пролета они многочисленны на озерах Гусино-Удинской долины. В последних числах мая чернети начинают гнездиться. Гнездовыми стациями являются небольшие старицы и тихие протоки, с берегами, поросшими камышом, тростником, осоками. Поблизости воды среди этой растительности и располагаются гнезда. 11 июня на острове Гнилом мы нашли 5 свежих яиц в старом гнезде серой цапли, которое помещалось в тростниковых зарослях. 7 июля нам приходилось встречать пуховых птенцов на небольших озерах острова Харауз. В конце июля мы видели сборные выводки по 20-30 птенцов разных возрастов, которые находились около одной матки. 
На осеннем пролете стаи хохлатых чернетей на озерах долины р. Селенги появляются в конце сентября. Отлет продолжается до конца октября, когда здесь почти все водоемы покрываются льдом. На Байкале в районе дельты хохлатые чернети остаются до середины ноября.

Питается плодами осок, рдеста, моллюсками, гаммаридами, личинками стрекоз.

25. Гоголь Bucephala clangula (L.)

Бурят-монгольское название - Алаг нугаһан.

В дельте p. Селенги гоголь встречается в большом количестве только на весеннем и осеннем пролетах. Появляется он здесь рано, как только образуются полыньи на протоках. Прилет первых стай отмечен 7 апреля. Валовой пролет начинается с 20 апреля и продолжается до 20 мая. В первой половине мая гоголи обильны на всех озерах Гусино-Удинской долины, по р. Селенге и ее притокам рекам Чикой, Хилок, Уда. В дельте гоголи скапливаются на открытых сорах и крупных озерах.

В последних числах мая большая часть этих нырков покидает дельту и улетает гнездиться в северные районы.

Ближайшими местами гнездования являются северо-восточное побережье Байкала (Чивыркуйский залив и район нижнего течения р. Верхней Ангары), Баунтовские и Еравнинские озера. На осеннем отлете гоголи появляются в конце сентября, и пролет длится до конца октября. На Байкале в районе дельты стаи гоголей задерживаются до момента ледостава. После некоторые из них улетают на зимовку в район верхнего течения р. Н. Ангары.

Питается плодами осок, сусака зонтичного, ириса, рдеста, кувшинки малой, водяной гречихи, моллюсками, гаммаридами, личинками стрекоз.

26. Черный турпан Oidemia deglandi stejnegeri Ridgway.

Бурят-монгольское название - Хара ангир.

В дельте р. Селенги черный турпан встречается в качестве редкой пролетной птицы. Пролетавшую около устья протоки Шаманка стайку в 12 особей мы встретили 9 мая 1946 г.

Кроме дельты нам приходилось встречать этих птиц в окрестностях УстьБаргузина в долине р. Оронгой и по р. Темник, километрах в 50 выше р. Удунги.

По наблюдениям Э. Э. Пильмана (устное сообщение), черный турпан гнездится на горном озере Таглей. На гольцовом озере Баргузинского хребта 17 июля экспедицией Доппельмаира была добыта самка с развитыми яйцами.

В желудке самца, добытого нами 21 мая в долине р. Оронгой, находились гаммариды и озерные гольяны.

27. Каменушка Histrionicus histrionicus pacificus Brooks

Очень редко гнездится среди высокогорных озер Хамар-Дабанского хребта.

17 августа 1947 г. мы встретили выводок на горной речке Абрамихе, километрах в 15 выше места впадения ее в Посольский сор. Матка и 7 птенцов величиной с чирка спокойно плавали на небольшом плесе, изредка ныряя. При нашем появлении выводок, шлепая по воде крыльями, быстро скрылся за поворотом реки. Спасаясь от преследования, птицы затаились под корягами и нависшими над водой деревьями, матка же все время летала над укрывшимся выводком.

Добытый один молодой экземпляр весил 310 граммов. В его желудке находились личинки ручейников и два мелких хариуса. 
28. Большой крохаль Mergus merganser merganser (L.)

Большой крохаль, являясь обыкновенной пролетной птицей, на гнездовании в дельте остается в небольшом количестве. На весеннем пролете стайки крохалей появляются здесь в середине апреля и держатся на образовавшихся полыньях.

Весною большой крохаль прилетает небольшими стайками, по 10-12 особей. 29 мая на высоком берегу протоки Мотихи в густом ивовом кусту было найдено гнездо с девятью свежими яйцами. Лоток его был устлан стеблями осок, сухими листьями и пухом. 23 августа на Посольском сору мы встретили около 30 молодых особей разных возрастов. Заметив нас, птицы с шумом убежали по воде в открытый сор. При опасности крохали чаще всего убегают пешком по воде и только при настойчивом преследовании поднимаются на крыло. В середине сентября большая часть молодых птиц способна подниматься на крыло. К этому же времени и у взрослых птиц заканчивается линька пера. Крохали остаются в дельте до середины ноября.

В желудке 9 птиц, добытых в осеннее время, мы всегда встречали различных рыб - желтокрылых бычков, гольянов, сорожек. У одного экземпляра, добытого в августе на р. Абрамихе, в желудке было 6 мелких хариусов. Этот крохаль весил 1,2 кг.

29. Длинноносый крохаль Mergus serrator (L.)

B районе дельты в небольшом количестве встречается только на пролете. Весной они прилетают сюда парами в конце апреля и держатся здесь до 18 мая. Гнездовыми стациями длинноносого крохаля являются горные речки. В частности, он гнездится на р. Култучной. Гнезда его мы находили на северо-восточном побережье Байкала, около устья р. Кедровой. Выводки встречались по горным речкам Курбе, Оронгою, Убукуну. Осенью этот вид, так же как и предыдущий, остается в дельте до середины ноября.

\section{0. Луток Mergellus albellus (L.)}

Встречается только на пролете в большом количестве на осеннем. На весеннем пролете стайки лутков мы наблюдали в середине мая. На осеннем пролете лутки появляются в конце октября и первой половине ноября.

Приложения

\section{Основные виды защитно-кормовых растений водоплавающих птиц дельты р. Селенги}

1. Хвощ топяной Eduisetum heliocharis Ehrh.

Очень часто встречается в виде обширных зарослей и куртин на пониженных калтусах, по заболоченным берегам озер, протоков и стариц. Весной служит главным кормом всех гуменников. В небольшом количестве поедается косаткой и свиязью.

\section{2. Рдест пронзеннолистный Potamogeton perfoliatus L.}

Встречается в сорах, в глубоких озерах и протоках, образуя подводные сплошные заросли. Плоды служат для перетирания корма. В большом количестве поедаются хохлатой чернетью, гоголем и в меньшем - шилохвостью и косаткой. 
3. Сусак зонтичный Butomus umbellatus L.

Отдельными куртинами растет в авандельте около устьев протоков. Плоды поедаются гоголем.

4. Вейвик Дангсдорфа Calamagrotis Langsdorfii Trin.

Широко распространен, образуя сплошные вейниковые калтусы. Имеет защитное значение. В густом вейниковом покрове находят надежную защиту различные утки и нырки.

5. Манник водяной Glyceria aduatica Wahlb.

Растет по берегам озер, стариц и протонов. На мелководье соров встречается отдельными куртинами. Имеет защитное и отчасти кормовое значение. Семена в небольшом количестве поедаются лесным гуменнином, кряквой, шилохвостью.

6. Тростник Phragmites communis Trin.

Встречается сплошными бордюрами и отдельными куртинами в авандельте по заболоченным берегам озер и протоков. В густых зарослях тростника укрываются многочисленные утки и нырки.

7. Камыш озерный Scirpus lacustris L.

Встречается чаще всего отдельными куртинами по топким калтусам берегам озер и протоков. Имеет защитно-кормовое значение. Плоды поедаются кряквой, косаткой, шилохвостью, чирком-свистунком.

\section{8. Осоки Carex}

В районе дельты произрастают 16 видов осок (18). Повсеместно распространены и вместе с злаками (вейником, щучкой) являются господствующей ассоциацией. Зеленые стебли поедаются гуменниками и некоторыми утками. Плоды, главным образом, осоки топяной (Carex limosa), осоки нитевидной, осоки пузырчатой (Carex vesicaria) в небольшом количестве поедаются кряквой, шилохвостью, свиязью, чирком-свистунком.

9. Ряска трехдольная Lemna trisulca $\mathrm{L}$.

Встречается на всех мелких озерах и старицах. В небольшом количестве поедается утками.

10. Косатик болотный Iris pseudacorus L.

Часто встречается среди осоко-вейниковых зарослей по берегам озёр, протоков и на топких местах калтусов. Семена поедаются гоголем.

\section{1. Ивы Salix}

За исключением полосы дельты, прилегающей непосредственно к Байкалу, ивы распространены повсеместно. Растут главным образом по берегам протоков, образуя здесь густые кустарниковые заросли. Среди зарослей ив в большом количестве гнездятся кряквы, косатки, чирки.

12. Щавель Rumex aduaticus L.

Встречается на небольших озерах и старицах и по заболоченным берегам протоков. Семена поедаются кряквой.

13. Гречишка земноводная Golygonum amphibium L.

Растет на сырых на калтусах, по берегам озер и протоков. Семена поедаются кряквой, шилохвостью и красноголовым нырком. 
14. Кувшинка и кубышка Nymphala candida et Nuphaa lutetun.

Широко распространены в прибрежной полосе соров, на озерах и мелких протонах, образуя сплошные ковры на зеркале воды. Семена поедаются кряквой, шилохвостью, чирком-свистунком, красноголовым нырком.

\section{5. Вахта трилистная Menyanthes trifoliata L.}

Встречается в виде обширных сплавин по берегам соров. озер и стариц. Семена вахты в большом количестве поедаются кряквой и другими утками.

\section{Литература}

1. Бестужев Н. А. Гусиное озеро // Декабристы в Бурятии. Верхнеудинск, 1927. С. 41-78.

2. Бутурлин С. А. Полный определитель птиц СССР. Москва; Ленинград, 1935. Т. ІІ. $280 \mathrm{c}$.

3. Бакутин М. Г. Материалы по орнитофауне Еравнинских озер // Труды Бурят-Монгольского государственного пединститута. 1940. Вып. 1. С. 80-94.

4. Верещагин Г. Ю. Байкал. Иркутск: ОГИЗ, 1947.

5. Вотинцев Н. Н. Наблюдения над миграцией пластинчатоклювых в районе верхнего течения р. Ангары // Труды Восточно-Сибирского государственного университета. 1942. Т. 2, вып. 3. С. $68-88$.

6. Доппельмаир Г. Г. Соболиный промысел на северо-восточном побережье Байкала. Верхнеудинск: Изд-во Госплана БМАССР, 1926. С. 5-40.

7. Дыбовский Б., Годлевский В. Предварительный отчет о фаунистических исследованиях на Байкале // Отчет о действиях Сибирского отдела Русского географического общества за 1869 г. СПб., 1870. С. 157-204.

8. Радде Г. Озеро Байкал // Вестник ИРГО. 1857. С. 1-56.

9. Туров С. С. Материалы по фауне птиц Баргузинского края // Сборник трудов профессоров и преподавателей гос. Иркут. унив. 1923. Вып. IV. С. 132-169.

10. Тугаринов А. Я. Северная Монголия и птицы этой страны: предварительный отчет зоологической экспедиции в Северную Монголию за 1926 г. Ленинград: Изд-во Академии наук СССР, 1929. С. 145-236.

11. Третьяков А. В. К орнитофауне острова Ольхона по наблюдениям экспедиции 1933 года // Труды Восточно-Сибирского государственного университета. 1934. № 2. Москва; Ленинград. С. 118-133.

12. Житие протопопа Аввакума, написанное им самим. СПб., 1904. 27 с.

13. Иванов А. И. Птицы Якутского округа: материалы комиссии по изучению Якутской АССР. Ленинград, 1929. Вып. 25. 206 с.

14. Коновалов Н. А. Очерк растительности дельты р. Селенги // Труды комиссии по изучению озера Байкала. 1930. Т. 111. 34 с.

15. Козлова Е. В. Птицы юго-западного Забайкалья, Северной Монголии и Центральной Гоби. Ленинград: Издательство Академии наук СССР, 1931. 396 с.

16. Маак Р. Путешествие на Амур в 1855 г. СПб, 1859. 556 с.

17. Моллесон В.С. Краткие сведения о распределении птиц в окрестности г. Троицкосавска. Иркутск, 1896. С. 7-12.

18. Новиков Г. А. Промыслово-охотничья фауна северо-западного Забайкалья // Труды Бурят-Монгольской комплексной экспедиции. 1922. Москва; Ленинград: Академия наук CCCP, 1937. С. $78-92$.

19. Птицын В. Селенгинская Даурия. 1896. 307 с.

20. Павлов Е. Звери и птицы Читинской области. Читиздат: ОГИЗ, 1948. 151 с.

21. Фетисов А. С., Якубовская Г. В. Грызуны дельты р. Селенги / Иркутский гос. университет им. А. А. Жданова. Иркутск, 1947. 26 с.

Статья поступила в редакцию 12.10.20; одобрена после редактирования 16.12.20; принята к публикации 18.12.20. 